\title{
Singing Thy Sweet Radiance Encircling the Gem like World: A Comparative Study between Gerard Manley Hopkins and Rabindranath Tagore
}

\author{
Mohammad Kaosar Ahmed (Corresponding author) \\ Assistant Professor and Head \\ Department of English Language and Literature, International Islamic University Chittagong, DC, Bangladesh \\ E-mail: kaosarahmed@rocketmail.com \\ Sultana Jahan \\ Assistant Professor \\ Department of English, Northern University, Bangladesh
}

Received: 21-02-2013

doi:10.7575/aiac.ijalel.v.2n.3p.211
Accepted: 03-04-2013

Published: 01-05-2013

URL: http://dx.doi.org/10.7575/aiac.ijalel.v.2n.3p.211

\begin{abstract}
Rabindranath Tagore, the first Nobel- Laureate in the Indian sub-continent journeyed all spheres of the domain of Bangla Literature in $19^{\text {th }}$ century. His works are viewed in the West as spiritual and mercurial. On the other hand, Born in Victorian England and being influenced by the Oxford Movement, Hopkins decided to convert into restricted form of Catholicism, Jesuit life that made him culturally isolated. Despite having different religious and socio-cultural background their central philosophical concern is in most cases similar. Shading light on their views about nature, devotion to God, spiritual agony, this article goes deep into their values and beliefs and makes an analogy between them.
\end{abstract}

Keywords: Agnosticism, God, Nature, devotee, religion

Born in two different realms and having different socio-religious perspectives, Hopkins and Tagore shared a considerable amount of similarities in their poetic notion. Hopkins is a religious poet whereas Tagore's is considered mystic and romantic poet. Belonging to the same poetic era - that is, Victorian whirlwind, both poets remained devoted believer throughout their lives. In spite of the manifestation of the influence of English literature on Tagore's works, his religious belief and devoutness were the main inspiration of his poetic perception; his firm faith and religious zeal avowed in Gitanjali astonished the Europeans. Likewise, Hopkins standing apart from the Victorian ethos converted into Jesuit and devoted himself to priesthood. Both of them instead of being influenced by the whirlwind of the Victorian epoch, overwhelmed the poetic world with their earnest belief to God. Tagore was awarded Nobel Prize for Gitanjali, a magnificent manifestation of devotion to God. Having different religious standpoint they held a strong affinity regarding the love for God, and views about nature and spiritual dilemma. Every devotee undergoes duality during their spiritual journey. Tagore and Hopkins were not exceptions. Each poet suffered emptiness and non-communication with God but their spiritual depression by no means was replaced with agnosticism. Their affinity regarding spiritual conflict surprises us as both of them expressed displeasure in the ways of God immediately before their death.

Their different religious standpoints, to some extent, predisposed their views of God and nature. According to Tagore, the infinite has to be realized by the individual in his intuitive experience. Intellect is insufficient to reveal truth that is revealed in intuition. He felt the existence of God within himself and while singing felt merging with God. He spoke out with ecstasy: "I look to thy face, and tears come/ to my eyes." (Bhattacharyya and Chakraborty, 2007, p. 17)As he did not believe in institutionalized religion, he did not allow himself to be in touch with the pain and suffering of the world. Even he went to the extent of saying that deliverance cannot be achieved in renunciation. He says, "deliverance is not for me in renunciation"/ I feel the embrace of freedom in a thousand bonds of delight." (Bhattacharyya and Chakraborty, 2007, p. 64) According to him sensory pleasure will bear God's delight and he never shut the door of his senses and held that true religion preaches freedom, whereas institutionalized religion will make it slave. He revels in flights of imagination without any constraint and poetry gives free play to his spirit that corresponds with God through nature. However, Hinduism, to a great extent, influenced his works. The core belief he took from Hinduism is that the universe is a partial manifestation of the Infinite Spirit and true knowledge is the perception of the unity of all things in God. He believed with all his heart that the emancipation of humankind consists in our absolute self-surrender in service and love.

By contrast, Hopkins was searching for a perfect institutionalized religion that would pave the way to spiritual perfection. He first came under the sway of the Anglican High Church and the Oxford Movement and then was influenced by the great Catholic John Henry Cardinal Newman. In the middle of the nineteenth century, many British 
thinkers and theologians converted into Catholicism under the influence of the Oxford movement. Under the guidance of Newman, Hopkins also converted into Catholicism and joined the Jesuit order. For spiritual accomplishment and being convinced by the fact that only religious restrictions can subdue the evils and stubbornness of human soul, he embraced the hardship of Jesuit life. Unlike Tagore he was swayed that deliverance would come through renunciation of his Jesuit life; his sense of denial went to the extent that he burnt all the manuscripts and resumed to exercise poetic talent only when he perceived that through writing poems he would serve Christ and God.

The worth mentioning similarity between the two poets is that their religious belief was conspicuous upon their poetic spirit. In most cases, Hopkins employed institutional elements of religion like the idea of trinity whereas Tagore believed in the spontaneity of religion and considered poetry to be his religion. Though Hopkins was a priest, he felt ecstatic when he beheld the beauty of nature declaring the warmth presence of God. Consequently, complexity arose from the dual aspect - his priesthood and poetic sensibility. Rabindranath, on the other hand, was a romantic poet and somewhat, a mystic poet as he was the worshipper of beauty and God. Nevertheless, immediately before his death Tagore also underwent spiritual duality. He was the true follower of his Lord and felt very much delighted to sing praises unto the Lord almighty. He felt like drinking "with the joy of singing I forget myself and call thee/ Friend who art my lord." Tagore, though, was an earnest devotee, unlike Hopkins he was against all the religious restrictions and bondages. But like Hopkins he wanted the Lord to be with him and strengthen him: he cried, 'I want thee, only thee'.

Regardless of their religious belief, their devotion to God is persistent and this unrelenting fervor is reflected in their devotional poems. Gitanjali is his manifestation of Tagore's firm faith and love for God. It expresses the yearning of the devotee for the reunion with the divine. That human existence is worthless without the presence of God is reflected in the following poem:

\author{
Thou has made me endless, such is \\ thy pleasure. This frail vessel thou \\ emptiest again and again, and fillest it \\ ever with fresh life. (Bhattacharyya and Chakraborty, 2007, p. 20)
}

The infinite is bloomed into our soul and the sweetness of merging finite with infinite declares the existence of the greater soul. At this point the poet felt the enthusiastic presence of God within himself. The human body is the temple of God; hence it needs to be kept pure. Our effort should be to reveal God in our actions because it is God who gives us the power to act. This is true worship. Conversely, the simplicity and freshness of faith lost its cheerfulness as his spiritual vision became complex in later poems.

Each poet used his poetry as an avenue to express his love and praise to the Creator, and not only wrote about the beautiful part of faith, but also recorded their suffering caused by sterility that inevitably comes during one's spiritual journey. Tagore perceived that without supreme, human soul is meaningless. And he felt the presence of God in soul which filled him with unspeakable pleasure. Like Tagore Hopkins' central philosophy is that men are created to praise God without whom the existence is meaningless.

In Hopkins' "The Wreck of the Deutschland" this concern is given superb expression. The poem reflects his belief in the doctrine that human beings are created to praise God. The poem centers round five Franciscan nuns and their dying. They were drowned between midnight and morning when light penetrated the darkness. Then they were with God upon another shore and in a greater light and were at peace, while the poet remained on earth with all the uncertainty and strain:

\author{
I am soft sift \\ In an hourglass-at the wall \\ Fast, but mined with a motion, a drift, \\ And it crowds and it combs to the fall ;( Gardner, 1953, p. 120)
}

This poem started with the assertion of God's supremacy and dominion in the universe. God is the creator and preserver. He is both above and within the world, and master of sea:

Thou mastering me

God! Giver of breath and bread;

World's strand, sway of the sea;

Lord of living and dead; (Gardner, 1953, p. 120) 
Hopkins's discernment and sensitivity about God is hinted here. God is the master and man must show his submissiveness. He demonstrated both God's mastery over human being and over the whole world. The poem also confirms God's mercy upon human being. Drawing several images to elaborate the love and terror, of God, the poet deals with the fear of God. It is determined on individual religious experience which is always related to test and suffering. Tagore also does not keep out test and suffering from while talking regarding his love for God.

Both Hopkins and Tagore observed in their nature poems, undisturbed beauty and harmony as their minds were filled with praising of God. Hopkins praised Christ through the objects of nature while Tagore felt the presence of his Jivan Devata in the midst of nature. The idea of God the Son and Holy Ghost are prevailing specially in his poems of nature. If the God is the master of all things, Christ is the king, and then the Holy Spirit is a presence. In 'God's Grandeur' God's elegance is pervading the whole world and the nature is declaring the presence of God. The idea of trinity is clearly manifested in his nature poems. Hopkins in the midst of nature felt ecstasy which took possession of him as he looked at the object of nature. Then he diverted the ecstasy into a religious channel. Hopkins is a keenly sensuous poet and a Roman Catholic priest at the same time his poetry bears the unmistakable stamp of his poetic sensibility and devotional fervour.

"Pied Beauty" points to Hopkins' power of sensuous appreciation of the beauty of the things around, his poetic concentration, compassion and above all, his unquestioning faith in God. The very expression "Pied Beauty" means various colors and beauty of things. The uniqueness of their ever changing colour and forms is very much pleasing to the poet. But the realization that they all are the manifestations of the beauty and grace of the supreme creator overflowed his heart with wander and admiration.

The realization that each and every ordinary object of the world of nature has the touch of a magic hand of the supreme artist prompts one to worship and sing the glory and grace of God. The sky of couple colour brings the association of spotted cows. The trout that swims have on them rose-spot on dots beautifully distributed. The chest nuts that falling from the trees is bright red in colour like glowing coal in a fire. Hence, the natural world with its varied forms of beauty has its appeal to the sensuous poet, but he saw it in the light of his devotion. It appears definitely more beautiful. He found each and every object of nature glowing with the glory of God and carrying to him the intimation of divinity. Thus the poet concluded his poem with an invitation to all to praise the glory and grace of God.

Tagore expressed similar kind of joyous and ecstatic mood while he wrote nature poems and felt the presence of God behind them. Both Tagore and Hopkins were poets of spirit and their mysticism pooled two themes: love for natural world and passion for God. Using flowers, river, flying gees, roaming clouds or mountain Tagore infused sensuousness with mysticism and divinity. One of the hymns from Gitanjali starts off by asking a rhetoric question- who is the creator of such beauty of nature. His use of rhetoric question mirrors his enthusiastic mood and love for God.

\author{
Who set adrift? \\ The white cloud raft \\ In the blue sky (Bhattacharyya and Chakraborty, 2007, p. 12)
}

\begin{abstract}
He tended to spiritualize the moods of Nature ; in Balaka the dynamism of flying geese instilled into him a sense of immortality as he aspired to go "'Not here, but somewhere, somewhere, somewhere beyond!'. Like other nature poets he took delight in sensuous descriptions and beneath such enchantment he searched for the spirituality. Tagore's Gitanjali is endowed with richness of diction and imagery. The common objects of nature like flowers, rivers, clouds, the sky, the stars, the, rain, and cloud, wind and rising river, boatmen, lamps, temples and gongs, flutes and vines, birds ---this imagery are endowed with spiritual significance. Tagore compared his joy with that of the glad flight of a happy bird. He identified his own joyous mood with the happy mood of nature. We find the gleeful tone in the voice of Tagore "and my adoration spreads wings like a glad bird on its flight across the sky." (Bhattacharyya and Chakraborty, 2007, p. 7) In this song, Tagore presented the idea that the mystic bliss results when one devotes one's talents to the worship of God. In such moments the human soul raises high to become one with God.
\end{abstract}

Each poet discerned the glory of God in the world of Created things. In poems like "God's Grandeur", according to Hopkins the world is an outward manifestation of the magnificence of God and as such its purpose is to praise God. Whenever Hopkins observed the beauty of the created universe he recognized the shaping hand of God behind it: "I feel thy mine and find thee" (Gardner, 1953, p. 120). The impassioned feeling roused by minute observation helped Hopkins integrate the artist with the priest, or in other words, the physical and the spiritual. In "God's Grandeur" the poem begins thus:

The world is charged with the grandeur of God

It will flame out, like shining

from shook foil; (Gardner, 1953, p. 98) 
The world is the world of nature, the world of created beauty which is pervaded by the power of God; but the power is latent and it may reveal itself any moment in the manner of the sudden flash of lightning.

All nature is good;

Because the Holy Ghost over the bent

World broods with worm breast and with oh!

Bright wings. (Gardner, 1953, p. 98)

He believed that the created beauty is the reflections of God's spirit, and the beauty of nature is constantly reborn and renewed through the brooding of the Holy Ghost over the bent world. Nature has been polluted and violated by man's industrial activities. Yet the beauty of nature is never exhausted because,

The world is charged with the grandeur of God.

It will flame out, like shining from shook foil;

It gathers to greatness, like the ooze of oil crushed. (Gardner, 1953, p. 98)

God is in and over nature like the dove brooding over its young ones with protecting care and affection. The Christian concept of God as love and protector is vividly expressed in the last two lines of "Pied Beauty":

He fathers forth whose beauty is past change:

Praise him. (Gardner, 1953, p. 130)

The following verse expresses the idea that even though there is an abuse of man against nature in order to obtain pleasure and benefits, "he doesn't have the power to destroy it altogether": "lives the dearest freshness deep down things". The terms "deep down" refers to that "rejuvenation of nature", and at the same time the "rejuvenation of man through the presence of the Holy Spirit". The poem concludes making reference to this Holy Spirit who is still protecting the whole world: "the Holy Ghost over the bent world broods with warm breast and with ah! bright wings. Hopkins believed in trinity that is associated with his use of imagery. Tagore was, conversely, a monotheist and his idea of God was different from Hopkins. Despite their having different standpoint, their idea of love, mercy, and above all the grace of God that is "continually showered" in the universe is amazingly similar. To substantiate the idea that God is pervading the whole world Hopkins used the image of Holy Ghost and its "bright wings" and Tagore used the image of "thy feet lies encircled the gem like world' and compared "earth with the "shed the fountain of thy fascinating sweet radiance". Tagore also in the midst of nature saw that the sky, the stars, the moon---everything was encircled with the eternal rays.

Tagore's "O Thou Truth and Beauty Dwell in This World of Joy and Hallowed Light" declares the revelation of God's elegance and comeliness through nature. Even the freshness of cycles of day and night is the upshot of the ever-present radiance of God"

The grandeur of thee is revealed in the vast sky

At thy feet lies encircled the gem like world

The planets and stars, the moon and the sun in restless speed

Are drinking and bathing in thy eternal rays.

On this earth is shed the fountain of thy fascinating sweet radiance

Flowers and twigs, song and scent bid thee a sweet welcome.

Life flows day and night with eternal freshness

Thy grace is continually showered in birth and death.

Affection and love, mercy and devotion make life endearing

Thy shower of consolation takes the grief away.

The universe is singing of thy great fest in the world

The wealth of beauty, the world's abundance rests safe in thee.

(Chaudhuri, 2004, p. 87)

The universe including the world of created beauty is delimited by the power of God. Tagore used "gem", "bathing and drinking" rays to express God's grandeur while Hopkins used "flame out, like shining from shook", "Bright wings", dove brooding over its young ones" to show God's pervading presence in the world. Both poets used the image of freshness in the form of love and devotion that is insistently rejuvenating the nature. God's love in the form of sweetness and safety encircle the world where every object of nature is flourishing with "eternal freshness". As a nature 
poet Hopkins and Tagore are similar in the sense that neither did they exert pantheistic view nor they overvalued nature; they praised God glorifying the objects of nature.

They not only observed the warm and affectionate presence of God rather pitifully noticed the inconsiderate and destructive act of human being upon nature. While considering the holiness and devoutness at a deeper level and finding the world charged with spiritual influence, they pitifully observed the man's destructive attempt to impede its inbuilt activities. Not only did this event change their perception on a spiritual level, it also affected their general tone and outlook on life, which was evident in the way the poets wrote in "God's Grandeur" and "I plucked your flower".

The problems both poems directly address are focused on the exploitation of nature in pursuit of wealth and material gain. Mankind abused the natural world and preferring to pollute it as a means of gaining wealth. Despite all the bad actions of mankind, ...there is a incessant presence of God who protects us, "the world goes on being a wonderful place thanks to him". The poem "God's Grandeur" uses Hopkins' as his agent. This poem shows that no matter how significantly humans destroy nature, God's life force will never be smothered out.

Rabindranath believed that to satisfy human being's hunger to create, they tremendously hold up nature's activities by destructing or taming. Tagore denounced human's enmity on nature and the tendency to enslave the objects of nature. In the poem "I plucked you Flower" human belligerence gets expressed through the plucking of a flower. Human being fails to view nature as the manifestation of God, uses its beauty as commercial purpose. In the following poem the speaker's business motive rather than aesthetic pleasure is stressed by using the phrase 'flower-gathering'.

More flowers will come to you with perfume and

Pride, O world!

But my time for flower-gathering is over, and through

The dark night I have not my rose, only the pain remains.

(Chaudhuri, 2004, p. 90)

Tagore here was different from Hopkins in the sense that Hopkins glorified the ever-present grace is working against the disgraceful activities of human being whereas Tagore condemned our tendency to domesticate and destroy natural activities for our purpose and as a visionary Tagore predicted that nature would react someday.

In "Fruit Gathering", Tagore directly opined that no one should interfere with the activities of nature, "No it is not yours to open buds into blossoms". According to him, human being does not know how to interact with nature. They "Shake the bud" and "strike it Tagore emphatically says,

.....it is beyond your power to

make it blossom.

Your touch soils it, you tear its petals to pieces and

Strew them in the dust.

(Chaudhuri, 2004, p. 102)

Men have the habit of destroying something to create something new. Both poets are reproachful regarding human activities. Hopkins argues in "God's Grendeur" that despite the interdependent deterioration of human beings, God has not abandoned the Earth 'And for all this nature is never spent' (Gardner, 1953, p. 98). Hopkins created a sense of hope and renewal by showing an image of God as one who 'broods' over the fallen world. Similar to a nurturing mother, the 'warm breast' nurturing the baby bird as God protects the world. Tagore, however, did not manifest any hope as reflecting on human nature he observed the tendency of human nature only to destroy to create new.

Both poets very passionately illustrated the rapturous presence of God in every object of nature. But they are not without spiritual dilemma - both of them felt the worlds pervaded with the sweet radiance of God but as they looked into the depth of their soul, they found a kind of emptiness that was caused not by faithlessness but by their craving for the warm touch of God. In "Nishphal Kamona" Tagore says:

The evening star comes in the wake of departing day And the breath of twilight is deep with the fullness of a farewell feeling. ...with my hungry eyes;

Seeking and crying, where art thou,

Where, O, where!

Where is the immortal flame hidden in the depth of thee!

(Chaudhuri, 2004, p. 121) 
Every earnest devotee encounters some sorts of change during their spiritual pursuit. Tagore and Hopkins were no exception. This cry "Where, $\mathrm{O}$, where" is not the distress of an agnostic, but craving of a devotee for "immortal flame hidden in the depth of thee". Their yearning to find out God encountered obstacles during their spiritual journey. But such obstacles cannot shake their faith; rather in Gitanjaly Tagore earnestly prays to God so that he may overcome all the worldly difficulties that would instigate his selfhood, a bar to attain spiritual perfection. Tagore earnestly prays to God in "Attotran"so that he may raise above "daily trifles", "root of penury" and can surrender to the will of God. Hopkins' problem regarding the surrender to the will of God is more complicated. In Hopkins' case the extra sensitiveness about self was the only obstacle in going near God. Though their approach was different, each knew very well that self-surrender to the will of God is the key to our relationship with divine.

As Tagore underwent spiritual complexities, his vision became mature. In the afore-mentioned poem he was feeling a kind of emptiness caused by the non-communication with God. His feeling of hollowness and despair reached the peak in his Sesh Lekha. Yet, he never gave up the belief that total surrender to the will of God is the only way to attain spiritual perfection. Hopkins, though an earnest devotee, had some complexities in his spiritual faculty. In some of his terrible sonnets he recorded his inability to surrender his selfhood to the will of God. In the sestet of the poem “'I Wake and Feel the Fell of Dark, Not Day', Hopkins' main reason for spiritual crisis was affirmed in a suggestive way:

I am gall, I am heartburn. God's most deep decree

Bitter would have me taste: my taste was me;

Bones built in me, flesh filled, blood brimmed the curse.

(Gardner, 1953, p. 210)

The body is a loathsome prison to the soul and it captivates the soul which aspires to rise and returns to the Eternal Bosom. The focal reason for Hopkins' spiritual crisis was confirmed in this poem. Absolute surrendering to the will of God always contradicts with excessive consciousness of one's own identity. That is why, he struggled hard to set himself free from the inescapable ego of greed and selfishness which he loathed most. In spite of dark agony and the deplorable condition of his soul, he struggled for the uprightness against fleshly evils.

Both of them expressed spiritual discontent and questioned the mysterious ways of God. And surprisingly, they divulged such spiritual barrenness immediately before their death. Hopkins recorded his black hours of spiritual agony in terrible sonnets and Tagore reflected his faith-crisis and non-communication with God in his Sesh Lekha.Terrible sonnets were written due to frustration over his poems being ignored and his preaching being a disappointment. It was written two months before his death. Hopkins was a Jesuit priest with a profoundly mystical nature. He believed in total obedience to the will of God to the will of his spiritual superiors.

Towards the end of his life Hopkins found himself in a state of deep spiritual depression, or what is sometimes known as the "dark night of soul". Essentially, he felt that, despite all his fervent attempts to serve his Lord, God was not responding with any perceivable blessing — on the other hand, those people whom he regarded sinners appeared to live very fruitful life. Hopkins went to a consideration of the inequities of life, and, implicitly, to a speculation about God's justice. We find paradoxical attitude in "Thou Art Indeed Just, Lord", when he asks God, "Wert thou my enemy, O though my friend,/ How wouldst though worse, I wonder, than thou doest/ Defeat, thwart me?" (Gardner, 1953, p. 230). At the end he called on God to send his roots rain. Hopkins admitted that God is just. He saw that there must have been a disconnection between the human and divine understanding of justice. He also perceived that this disconnection was caused by spiritual barrenness and this discernment prompted him to call on God to send his 'roots rain'. It was the rain of spiritual fruitfulness which Hopkins wanted. This spiritual affluence reinforces the devotee to endure all types of injustice and deprivation inflicted upon the believer as a test.

Their spiritual suffering reached its peak when both poets felt scared stiff by the sense of separateness with God; Hopkins used the image "dead letters sent" to expose the cruel silence of God. Tagore considered it to be deception. However, he never gave up himself in despair. Immediately before his death the poet reflected his deep perception about life and death in Sesh Lekha. His perception at that time seemed paradoxical. Tagore in his poem "Tomar Srishtir Path", (Your Way of Creation) addressed God calling him deceiver as at this point the way of God seemed to him deceitful. The undertone of the word 'deceitful' is unfathomable mystery that pervades the whole world. Tagore says:

You make your creation scattered and swindled in mysterious

and impenetrable trap

Oh! Deceiver (Chaudhuri, 2004, p. 215)

Tagore here failed to understand the ways of God; he did not particularly mention the reason for his spiritual crisis. He was in death bed when he wrote these lines. Unbearable physical agony and unexpected death of his wife and daughter and other worldly insufficiencies were intensified when all his pleas were answered with cold silence of 
God. During the end of the poem his mood of unintelligibility turned to resolution as then his spiritual state seemed serene and tranquil. Now the significance of the word "deceiver" was disclosed as he realized:

He, who tolerated this deception without exertion,

Get eternal right of peace by your hand (Chaudhuri, 2004, p. 215)

Here deception is a kind of acid test which a devotee must endure and prevail over during his spiritual pursuit. The hope of eternal salvation thus turns aside a devotee from all types of despair.

Immediately before their death each poet was on the verge of a grave spiritual condition. Both Hopkins and Tagore were terrifically suffering from a sense of separateness from God. The sense of separateness causes sorrow which is the part of the man's greater existence and most poignant truth of their life. This gap between human and divine will be ended only when the man accepts His ways to men and having blind faith moves to the infinite to be united with the greater soul. After a tremendous spiritual suffering they flew like the flock of geese flying to the Infinity, Balaka/ ("The Flight of Wild Geese").The same was expressed in Hopkins immediately before his death. Nevertheless, he must have been contented with the blissful reunion with his beloved God in afterlife. Hopkins's last words, repeated over and over, were an affirmation — or a plea to himself: "I am so happy. I am so happy.”(Watson, 1989, p. 113)

Both poets were poles apart regarding religious belief, still similar regarding warmth presence of God in nature, spiritual conflict and tendency to influence the poetry with their religious perspective. Philosophical standpoint may vary from religion to religion, but feeling of devotion comes from within where both poets are similar. They had real appreciation for nature, they had spiritual agony, and they had the ability to feel the presence of God in nature. Regardless of their different religious perspective, they were aware of the God's supremacy over human being and of man's duty to unconditional self-surrender to the will of God. Both of them felt ecstatic in the midst of nature; yet they had spiritual conflict that put hindrance in the way of self-surrender. In the case of Hopkins it was more intricate and acute than Tagore. Hopkins identified the selfhood or ego was the only bar in reaching near God, whereas Tagore considered the reason for spiritual conflict to be the breach between human and divine understanding. During their spiritual journey, both poets encountered despair and felt like giving up faith. Yet they never became an agnostic as they expressed firm conviction for blind acceptance of God's way to man.

\section{References}

Gardner, W.H. (Ed.). (1953). Gerard Manley Hopkins: Poems and Prose. London: Penguin Books Ltd.

Chaudhuri, Sukanta. (Ed.). (2004). Selected Poems: Rabindranath Tagore. New Delhi: Oxford University Press.

Bhattacharyya, Subhankar and Chakraborty, Mayukh. (Ed.). (2007). Gitanjali: Song Offerings. Kolkata: Parul.

Watsan J.R. (Ed.). (1989). The Poetry of Gerard Manly Hopkins: A Critical Study. NewYork: Penguin Books Ltd. 